\title{
CLINICOPATHOLOGICAL STUDIES ON DIAGNOSIS OF LISTERIOSIS IN OSSIMI SHEEP
}

\author{
El-Boshy, M. E, and Gadalla, H. A. \\ Departinent of Cluucal Palhology, Faculty of Veteshary Mediclne. \\ Mansoura Untweralty. Mansoura 95516. Egypt
}

\begin{abstract}
Between (November 2008-March 2009) a number of 48 Ossinu sheep age 16-12 months) have neruous mantfestation and unestigated for suspect listeriosts. The diseases sheep were treated with amplallin and blood sample were collected from all diseases sheep before start the treatment. Dlagnosis was achieved by physical examinations, clinical fuudings, isolation and identification of microorganlsm laboratony inuestigations The selected sheep were calegorized into survied group and non swvilued group in additton to the control group.

Oxtdative stress and antioxidant parameters, our results show that SOD, and NO were signiflcant elevaied in boch responstue and non responsive treatment groups while MDA is slgniflcant increased anly in non responsice treatment group in compare with contral group. Total proteln, $C K$, wric acld, urea and creatinine result show signiflcant elevated in blood level in non-surulved group in compure with conirol one. Regarding to the leukogram there is leukocytosis, neutrophilia in responsive treatment group and tymphopenta in ron-responswe group.

In conclusion the axidative stress, and antioudant blood parameter's are valuable in prognosis the listeriasis in Ossimi sheep.
\end{abstract}

\section{INTRODUCTYON}

Usteria monoeylogenes is a Granr-positlve pathogeruc bacterfum facultative intracytosolic that has adapted to varlous environments, from solls and food products to the Inteatinal tract and Intracellular compartments of diverse andmal spectes and humans. Nearly all the domestic animals are suseeptible to Listcria Infections, but anlmal listeriosis most commonly occurs in ruminanta (Cooper and Walker, 1998). The maln clinical features of ruminant listeriosis are cnccphalltis, septice- mla, abortion and mastitls (Low and Donachle, 1007 ).

The prevalence of encephalitic listeriosis was unexpectedly high when compared to nothed confluned cases in small ruminarts (Oevermann et al., 2008).

Haemato logical analysis in ovine lsterlusis have a uttie diagnostle value as leukocytosis Is not a consistent leature of listerdosls but only indicative of the passiblity of Infectlon 
(Brugo're-Picoux, 2008). serum analysis from sheep with ovine meningo-encephallus showed a significant elevation in the level of creatine klnase and aspartate aminotransferase and a signiflcant reduction in blood bicarbonate potasssum. total plasma proten, albumin and givcose levels (RL-samalhy et al., 1999) meanwhile, in another study, the blochemalcal finding in sheep and goats with listerlosis revealed a high coneentratton of total proteln, bilirubin, urea nitrogen and the animals had a metabollc acldosis (Braun et al. 2002). Amplcillin and gentanicln have been reported as the treatment of cholce for ilateriogts (Bruge're-Pleoux. 2008) .

Antloxddants, auch as gutathlone, argnine, citrulline, taurine, creatine, selendum.

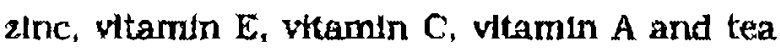
polyphenols help to regulate the ROS thus generated. Antloxidant is further supported with antioxidant enzymes, e.g. superaxdde dismutase, catalase. glutathione reductase and glutathlone peroxidase those exert symergistic actlons in removing free radlcals imbalance between oxddants (free radicals) and reductants (antloxddants) at the cellular or Individual level commony rcferred as oxddatue stress (Yun-zbong et al., 2002). Unfortunately the Immunomodulatory of listeriosis not lias been Investlgated in sheep as human and other domesuc andmals. Therefore the goal of our study to comparative hematological and bio. chemical changes asgoclated with survtral and non survival listerlosis in sheep.

\section{MATERIALS AND METHODS}

\subsection{Clinjeal Examination:}

A number of 48 Ossiml sheep in Mansoura Govemorate were examyned for suspect listert- asls. The history of discase was varlable from mlld to severe and characterized by general weakness. respiratory distress, circling movements with twist in the neck bestde unllateral Factal paralysis developed. Death within one week of the onset of clinical signs of some cases was recorded. The dlseases sheep were treated with amplelllen $20 \mathrm{mg} / / \mathrm{K}_{6}$ bw for one week and blood sample were collected from all diseaseg sheep before start the treatment. A selection total of eight nattve breed Ossimi sheep of both sexes aged between (6-12 months) were studied after diagnosed of usterlosis. Dlagnosls of such clinical condition was achleved by competent case history, thor. ough physlcal examinations, clinical flndings. isalation and identufication of microorganism. laboratory investugations. In addition to twenty apparently healthy Ossiml sheep of both sexes aged between (6- 12 months), were rardomly selected and were constdered as a control group. The selected sheep were categoroed into survived group and non survived group in addition to the control group. (Each group is elght. four females and four males].

\subsection{Bactarlological terestlgatlona:}

Samples for bacterlologlcal examination were collected from cerebrospinal huid and tlssues from hind braln (medulla oblongata. and anterior part of splnal cord) llver tung kddney and spleen from all dlseases sheep (re cent mortality sheep as well as which were sacrifleed at the ternunal stages on 6th day post clinical symptoms\}.

Samples were inaculated dirextly onto blood agar, MaeConkey's and MeBride's med:um. These samples were processed as per standard protocol of Gray and Eminger 
(1966) and vartous blochemical lests (moulity at $25^{\circ} \mathrm{C}$, aesculin hydrolys $1 \mathrm{~s}$, fernnentation of alpha methyl d-mannose. mannltol, ribose, rhamnose and xylose. nutrate reducton. methyl red and voges proskaucr) (or charac. terization of $\mathrm{L}$. monoeytogenes were perfornncd using a conmerclal system according to Seeliger and Jones(1986).

\subsection{Blood Sample日:}

Blood from the affected and healthy sheep was collected for haemato logical, blochemical and inmunological examination. Two types of venous blood samples (five anl for each) were collectcd via Jngular veln puncture from each sheep: the first blood sarnples added to $5 \mathrm{mg}$ sodium ethylene dlamine tetra acetic actd (EDTA) as anticoagulant for hematological evaluavion of total erythrocytlc cell counts, packed cell volume (PCV 06), hemoglolyln total and differental leucocytic count according to the method described by Coles (1088); whereas the second blood samples were collected into heparenzed syrnge to collect blood piasma which was separated quickly and kepl frozen for hlochemical analysis of aspertate amino Iransferasc (ASn). ALT, total billrubln and, total pro tenn. albumin, glucose, urea, creatintne and uric acld (UA) and superoxde dismutase (SOD). reduced glutathione (GSH) malondsaldehyde (MDA), nitric oxide, nilinc oxide (Blodlagnostle Egypt).

\subsection{Statlotical analysia:}

Data was subjected to statlstically analyzed by ANOVA test with posthock LSD multiple compartson test using statistical software program (SPSS for windows version. 15. (ISA). Differences were considered significant at $P<0.05$.

\section{RESURTS a DISCUSSION}

From total examined (48) diseases sheep samples from braln thssues and CSF, a (2l) Isolate was recovered. The Isolates were gray ish white small dew drop like colonies observed on blood agar whth narrow zone of $p$ haemolysis Growth was attalned on MacConkey's agar and on McBride's selectlve medlum after direct inoculation the organisms were present parallet to each ather grving stake appearance In groups of two or three or scattered singly with gram staln smear. Some organisms had attained the vertical position giving dot ike or cocel appearance. Confma. tory test results using the some commerclal chemlcal tests, the organlsm showed tumbiing motillty at 25 deg $C$. positive reaction for methyl red aesculln hydrolysis, feimentation of alpha methyl d-mannose and rhamnose, MR and voges proskauer. Biochemical tests were negative for nitrate. urcase, trdole rcduction and fermentation of mannitol, r1bose and xylose. No other significant pathogens were recuvered from the specimens. Also no significant pathogens were recovered fiom control groups. The epldemloioglc screenung of ovdne bocks could be a helpful preventive measure, especlally if rapift and sensitive di. agnostic procedures are employed and could represent an effectlve approach to the eptdcrnlological screening of ovme flocks.

Diagnosis of animal Hsterte infection is cirrrently achleved by microblological or histologlcal tesis.

Increase Incldence of listerlosis were recorded in the winter season INovemberMarch 2008) coild attributed to at this per1od weather conditions are favorable for the growth of bacterla due to very low environ- 
El-Bashy, H. E. and Gadalla, H. A.

mental tempcraturc and the ability of the $\mathrm{L}$ monocytogenes to grow very well al reduced temperatures compared to other mesophlic medically important microorganisms (Paul et al., 2000 \& Knmar et al., 2007). Our results partial agree with Al-Dughaym, et al., (2001) who recovery I. monocytogenes from brain and some cases from lung in oulbreak sepucaemic Usterios!s in sheep.

I.lpld peroxidation is known to have a role In many infectlous diseases. The mechanlsm of damage involves liptd peroxldation. which destroys cell membranes wtth' the release of Inlraccllular cornponents. such as lysosornal enzymes, leading to further llasue damage (Demir ot al., 2003). Our results show that SOD. and NO were signiflcan! elevated in in both responsive and non responsive treatment groups whlle MDA is significant increased inly in non responsive treatment group in comparc with control group. Malondlaldeliyde [MDA] is a by-product ol tlpid peroxddation and uged as an index oloxddatuve stress in cells and tssues (Cevat et al., 2007). Increase oxldatye strcss parameters In our work documented by elevation of MAD. SOD and uric actd and decrease anliaxidant parameters in non-survtved infectcd group. Lelb and Tamber (1999) * Ayclcek et ai., (2008), reported Increase oxddative stress and decrease antloxddarit blood parameters in patients sulfer from bacterial meningitus.

Ah mel and Ay sen (200n) a Fry et al. (1999). concluded the bacterial infection in shcep Induces Ilpld peroxidation, leatling to a rapld consumption of the antloxddant from the body.
The liver enzyme in our study is Insignincantly elevated in non-survived group in compare with both survived and control groups. Shaw, (2008). Zundel and Bernard (2006) studied experimental Infection of sheep with $\mathrm{L}$ monocytogenes and observed the all organs of gastrointestunal tract were infected included Ilver and spleen. Hepatopathy and hepatte necrosis as a result of listerosis were recorded in ahecp, lamb, calves, llama and guinea plgs (dark, et a.. 2004, Burdaror and BarovaBurderova, 1087, seimitya et al., 1092 semrad, 1904 Ellsabeth et al. 2008) respectively.

Hypoalbuminemla resulta from a derangement in one or more of these processea (Don and kaymen 2004). Hypnalbum!nemia In non-survtved sheep could be attributed to malnutrition and or liver dyofunction.

Glucose is non signilfeant in both survived and non-survived group in compare with control group. Sepsis. which causeg lnadequate glucase to be delivered to the body's cells, may also cause hypoglycemia (Thompeon 2008). Also hypoglycemla recorded assoclaled with bacterial infection in lamb (Burkhard and Garry 2004).

Creatine kinase leoenzymes are character. istic for skeletal muscle, myocardlum, and braln (Grayb and Gorkowatd 2008). The ele yation this enzyme in our work could be as a result of braln damage caused by listeriosis. Leston damage asaoctated with listeriosis in sheep has been reported by Brag'ere-Plcoux (2008), Eromar of a., (2007) and AlDughaym, et al. (2001). 
Regarding to kidney function test our result ohow sugnilicant elevated In urie acid, urea and creattnine blood levels in non. survived group. Low and Donachte (1001), Low and Reaton (1986), Evane, and Wateon (1987). reported the septicemte listerusis leslons were severe in brain, llver, spleen and lymph nodes in lamb, sheep and call respeettvely \& Kumar et al., 2007). Our results parthal agree with Al-Dughaym, et al., (2001) who recovery $\mathrm{L}$. monocytogenes from brain and some cases from lung in outbreak septicaemsc listerlosis in sheep.

Lipid peroxidation is known to have a role in many infectious digeases. The mechandsin of damage involves llpld peroxldation. whlch deytroys cell membranes with the release of Intracellular components, such as tysosomal enzymes. leading to lurther thaue damage (Demir ot al, 2003), Our results show that SOD. and NO were signiflcant elevated in in both responsive and non responsive treatment groups whlle MDA is signiflcant increased Inly in non responsive treatment group in compare with control group. Malondialdehyde (MDA) is a by-produeh of upli peroxddation and used as an Index ofoxidative stress in exlls and tissues (Cevat et al., 2007). Increase oxidative stress parameters in our work documented by elevation of MAD. SOD and uric acld and decrease antoxidant parameters in nou-survlved Infeeted group. Lelb and Taubar (1090) a Aycleek et al., (2008), reported increase uxidatve stress and decrease antioxidant blood paramelers in patents suficr from bacterial meningills.

Ah met and Ay sen (2007) \& Fry et al., (I903). concluded the bacterial Infection In sheep Induces IIpld peroxddation, leading to a rapld consumptlou of the antioxidant from the bouly.

The tyer enzyme in our study is insigniflcantly elevaled in non-Burvived group in eoms. pare with both survived and exntrol groups. Show, (2008). Zundel and Beriard (2006) studled experimental infeetion of sheep with $L$ monocytogenes and ubserved the all organs of gastrolntestunal traet were infected included liver and spleen. Hepatopathy and hepatic necrosis as a result or listerosis were recorded in sheep, lamb, calves, llama and guinea plgs (dark, et al., 2004, Burturov and BavovaBurdarova, 1987, Selmiya et al., 1092 Bemrad, 1004 \& Edizabeth et al., 2008) respectively.

Hypoalbuminemla results from a derange ment in one or more of these processes (Don and Kaysen 2004). Hypoalbuminema In non-survived sheep could be attributed to malnutrition and or lver dysfiunction.

Glucose is non slgnillcant to both survived and non-survlved group in compare with control group. Sepsis, which causes inadequate glucose to be dellvered to the body's cells, may also cause hypoglycemla (Thompeon 2008). Also hypoglyeemia reeorded assoclated wth bacterial inlection in lamb (Burkhard and Garry 2004).

Creattnc klnage lsoenzymes are characteristlc for skejetal muscle, myocardium, and bralı (Grzyb and Bkorkoweld 2008). The elevalion this enzyme in our work could be as a result of braln damage caused by listertosis. Lesion damage assoclated wth listerlosis in 
gheep has becn reported by Brug'ere-Plcoux (2008). Kamar et al., (2007) and $\mathrm{A}$ Dughaym, et al., (2001).

Regarding to kJdney lunction test our result show olgniflcant clevated in uric acld. urea and ercaturine blood levels in nonsurvived group. Low and Donachle (1001), Low and Renton (1986). Eranc, and Watoon (1987), reported the septlcenlc Ustertosis beslons were severe in brain. liver, spleen and lymph nodes in lamb, sheep and calf respectwely

Regarding to hematological data of our work is show leukocytasis, neutrophilia in rcsponsive treatment group and lymphopenia in non-responstve group-
Wood (1972) reportod anemia. leukocytosis. neutrophilia with lymphopenla in goats suffer from encephalide listertosts, this findIng in the with our hematological results. In the same aspect Joze ot al, (2008) obeerved anemka. neutrophilia and lymphoperla in catthe infected with $L$. monocytagenes. BrugerePicoux (2008) concluded that Leucocytosis is not a conslstent feature of the listeriosis in sheep and only indicates the possibillty of an infection.

\section{CONCLUSION}

We coneluded that blood oxidatue stress, antloxidant and leukogram parameters are valuable in prognosis the listeriogis in Ossiml sheep. 
E1-Boshy, H. E, and Gadalla, H. A.

Table (1): Hematologlcal values (mean values plusmn SE) in Cilnleally Healthy Sheep. Responsive and Non-Responsive Listerial Cases to Treatment.

\begin{tabular}{|c|c|c|c|c|c|c|c|}
\hline Groupe & $\begin{array}{c}\text { TLC } \\
10^{3} / \mu L\end{array}$ & $\begin{array}{l}\text { Lymaph } \\
10^{3} / \mu \mathrm{L}\end{array}$ & $\begin{array}{l}\text { Nentro } \\
10^{3} / \mu \mathrm{L}\end{array}$ & $\begin{array}{c}\text { Mono } \\
10^{3} / \mu L\end{array}$ & $\begin{array}{l}\text { Eosino } \\
10^{3} / \mu \mathrm{L}\end{array}$ & $\begin{array}{c}\text { Baso } \\
10^{3} / \mu L\end{array}$ & $\begin{array}{c}\text { Band } \\
10^{3} / 14\end{array}$ \\
\hline Cont & $14.81^{\mathrm{ab}}$ & $7.25^{a}$ & $6.19^{\mathrm{a}}$ & $0.40^{a}$ & $0.40^{\mathrm{a}}$ & $0.00^{\mathrm{a}}$ & $0.57^{a}$ \\
\hline$(n=8)$ & \pm 0.58 & \pm 0.53 & \pm 0.40 & \pm 0.15 & \pm 0.17 & \pm 0.00 & \pm 0.26 \\
\hline Responve & $16.93^{b}$ & $5.57^{\mathrm{ab}}$ & $9.62^{\mathrm{b}}$ & $0.38^{a}$ & $0.67^{\mathrm{a}}$ & $0.00^{a}$ & $0.49^{\mathrm{ab}}$ \\
\hline$(n=8)$ & \pm 0.45 & \pm 0.72 & \pm 0.71 & \pm 0.20 & \pm 0.10 & \pm 0.00 & \pm 0.15 \\
\hline No Responso & $13.22^{a}$ & $4.20^{\mathrm{b}}$ & $7.20^{\mathrm{a}}$ & $0.20^{\mathrm{a}}$ & $0.60^{\mathrm{a}}$ & $18.75^{\mathrm{a}}$ & $0.24^{\mathrm{b}}$ \\
\hline$(\mathbf{n}=\mathbf{8})$ & \pm 0.38 & \pm 0.86 & \pm 0.88 & +0.16 & \pm 0.09 & \pm 18.75 & \pm 0.00 \\
\hline
\end{tabular}

Table (2) : Difierent Serum Autioxddant Levels and Other Oxddative Stress Markers (mean values \& plusmn SE) in Clintcally Healthy Sheep. Responstve and Non-Rcsponsive Usterlal Cases to Trealunent.

\begin{tabular}{|c|c|c|c|c|c|}
\hline Groups & $\begin{array}{c}\text { MDA } \\
\text { nmol/mi }\end{array}$ & $\begin{array}{c}\text { SOD } \\
\mathrm{U} / \mathrm{ml}\end{array}$ & $\begin{array}{c}\text { GSH } \\
\mathrm{mg} / \mathrm{d}\end{array}$ & $\begin{array}{c}\text { Catalawo } \\
\mathbf{U} / \mathbf{L}\end{array}$ & $\begin{array}{c}\text { No } \\
\operatorname{mol} / 1\end{array}$ \\
\hline Cont & $5.46^{a}$ & $163.84^{2}$ & $1.35^{a}$ & $332.36^{a}$ & $16.05^{a}$ \\
\hline$\{n=8\}$ & \pm 0.33 & \pm 3.19 & \pm 0.16 & \pm 11.36 & \pm 0.41 \\
\hline Response & $8.26^{a}$ & $213.12^{b}$ & $1.25^{\mathrm{a}}$ & $378.19^{a}$ & $20.50^{b}$ \\
\hline$(n=8)$ & \pm 0.93 & \pm 9.27 & \pm 0.16 & \pm 39.34 & \pm 0.61 \\
\hline No Response & $13.87^{\mathrm{b}}$ & $213.00^{\mathrm{b}}$ & $1.16^{\mathrm{a}}$ & $383.50^{\mathrm{a}}$ & $18.43^{c}$ \\
\hline$(n-8)$ & \pm 1.42 & \pm 9.30 & \pm 0.12 & \pm 41.66 & \pm 0.53 \\
\hline
\end{tabular}


EI-Boshy, M. E. and Gadalla, H. A.

Table (3) : Serum Blochemleal values (mean values \pm SE) in Clinically Healthy Sheep, ResponsIve and Non- Responsive Listerial Cases to Treatment.

\begin{tabular}{|l|c|c|c|c|c|c|}
\hline \multicolumn{1}{|c|}{ Groups } & $\begin{array}{c}\text { ALT } \\
\text { U/L }\end{array}$ & $\begin{array}{c}\text { AST } \\
\text { U/L }\end{array}$ & $\begin{array}{c}\text { CK } \\
\text { U/L }\end{array}$ & $\begin{array}{c}\text { Creatintue } \\
\text { mg/al }\end{array}$ & $\begin{array}{c}\text { U. A } \\
\mathbf{m g} / \mathbf{d l}\end{array}$ & $\begin{array}{c}\text { Urea } \\
\mathbf{m g} / \mathbf{d}\end{array}$ \\
\hline Cont & $60.79^{\mathrm{a}}$ & $202.21^{\mathrm{a}}$ & $96.00^{\mathrm{a}}$ & $0.85^{\mathrm{a}}$ & $1.58^{\mathrm{a}}$ & $47.00^{\mathrm{a}}$ \\
(n=8) & \pm 0.59 & \pm 5.18 & \pm 5.24 & \pm 0.02 & \pm 0.16 & +2.44 \\
Reuponse & $57.62^{\mathrm{a}}$ & $196.72^{\mathrm{a}}$ & $141.25^{\mathrm{a}}$ & $0.90^{\mathrm{a}}$ & $1.68^{\mathrm{a}}$ & $49.25^{\mathrm{B}}$ \\
(n=8) & \pm 0.41 & \pm 6.53 & \pm 12.35 & \pm 0.04 & \pm 0.06 & +2.78 \\
No Response & $65.04^{\mathrm{b}}$ & $209.87^{\mathrm{a}}$ & $410.50^{\mathrm{b}}$ & $1.19^{\mathrm{b}}$ & $2.54^{\mathrm{b}}$ & $\mathbf{5 8 . 8 8 ^ { \mathrm { b } }}$ \\
(n=8) & \pm 2.39 & \pm 4.52 & \pm 46.71 & \pm 0.03 & \pm 0.13 & \pm 2.77 \\
\hline
\end{tabular}

\begin{tabular}{|c|c|c|c|c|c|}
\hline Croupe & $\begin{array}{l}\text { T. } P \\
\text { g/d }\end{array}$ & $\begin{array}{l}\text { Album } \\
\text { B/di }\end{array}$ & $\begin{array}{c}\text { Blobulln } \\
\text { g/di }\end{array}$ & $\begin{array}{l}\text { A / G } \\
\text { Ratlo }\end{array}$ & $\begin{array}{l}\text { Glucome } \\
\mathrm{mg} / \mathrm{dl}\end{array}$ \\
\hline Cont & $8.55^{a b}$ & $4.13^{a}$ & $4.42^{\mathrm{a}}$ & $0.95^{\mathrm{a}}$ & $70.75^{\mathrm{a}}$ \\
\hline$(n=8)$ & \pm 0.23 & \pm 0.15 & \pm 0.19 & \pm 0.06 & \pm 3.88 \\
\hline Responge & $7.82^{\mathrm{a}}$ & $3.23^{b}$ & $4.60^{a b}$ & $0.74^{\mathrm{a}}$ & $71.00^{\mathrm{a}}$ \\
\hline$(n=8)$ & \pm 0.38 & \pm 0.21 & \pm 0.36 & $\pm 0,09$ & \pm 6.66 \\
\hline No Reeponse & $9.87^{b}$ & $3.93^{\mathrm{a}}$ & $5.94^{\mathrm{b}}$ & $0.72^{\mathrm{a}}$ & $73.50^{\mathrm{a}}$ \\
\hline$(n=B)$ & \pm 0.87 & \pm 0.31 & \pm 0.70 & $\pm 0,08$ & \pm 6.33 \\
\hline
\end{tabular}




\section{REFERENCES}

Ahmod, E, O. and Ayeon, A. (2007) : Ser um vitamin $E$ and malondialdehyde concentrations in expertmentally induced mannhetmila (pasteurella) haemolytica infection in ewes fed dam mllk or cow milk after birth. Bull Vet Inst Pulawy 51, 207-211.

Al-Daghaym, A. M.; Fadl Elmula, A, Mohamed, Q. E,; Hogazy. A. A; Rodwan, Y, A: Honeay, F. M. T. and Oameel, A. A (2001) : First report of an outbreak of ovine scpticaente ligleriosls in Saudi Arabja. Rev. sci, tech, OfT. Int. Eplz, 20 (3), 777-783.

Ajelcok, A. Iscan, A, Erel, O., Atcall. M. and Selek, S. (2006): Total antloxklanl/ oxddant status tr mentrigism and meninglts. Pedlatric Neurology $35,(6), 382-386$.

Bancrof, J. P.; 6tevenom, $A$ and Tumer, D. R. (1990) : Theory and Practice of hiscopathologlcal teehniques 3rd ed. Clurechill. LIvingston. EdInburgh, London.

Braun, U.; Btehlo, C. and Ehrenteperger. F. (2002) ; Clinlcal Hindings and treatment of Isteriosis in 67 shecp and goats. Vet. Rcc. 150. 38-42.

Brug'ere-Plcoux, J. (2008) : Ovine listeriosis. Small Ruminant Regearch 78, 12-20.

Burdarov, I. and Savova-Burdarova, $S$. (1987) : Seasonal dynandes and the preventhon of the meningoencephaltic form of listerosis In lambs. Vet Med Naukd 24 (8):23-7.

Burkhard, M. J. and Garry, F. (2004); Artifactual hypoglycemla assoclated with heanotrophic mycoplasma infection in a lamb. Vet Clirr Pathol. . 33(4):244-8.

Cevat, N.; Gll, F. $Y_{\text {; }}$ Alper, C.; Sena. C. and cillay, C. (2007) : Investigation of serum nitric oxide and malondlaldehyde levels in cattle Infecred whth Brucella abortus. Arkara Inly Vet Fak Derg. 54, 159-160.
Clark, R. G.; Gul, J. M. and Swaney, 8. (2004) : Listerla monocytogenes gastroenterlUs in sheep. N.Z. Vel. J. 52, 46-47.

Coles, E. H. (1986) : Vetentnary Clnnical Pathology. 4th Ed., W.B Saunders Company, Phlladelphla.

Cooper, J. and Waller, R. D. (1908) : LIsterlosis. Veterinary Clinics of Norti America: Food Antmal Practice 14 [1], 113-125.

Demir, s.; Ylimaz, M.; Kaseoglu, M.; Akuhn, N.: Aalan, D. and Aydin. A. (2003) : Role of free radicals in peptic ulcer and gastrltus. Turk J Gastroenterol, 14, 39-43.

Don, B. R. and Knysen, G. (2004) : Serum alburnin: relatbonshtp to inflammation and nutritton. Semin Dlal. ; $17(6): 432-7$.

Ellzaboth, A. I.; Denlta, W.; Kenneth, A. V. and Mary, A. S. (2009) : Listeria monacytogenes infection in pregnant guinea pigs is asgociatcd with maternal liver necrosls, a decrease th matemal serum TNF-a concentratJon, and an increase in placental apoptosis. Reproductive Toxicology 26 [2], 123- 129.

El-8awallhy, A. A.: Foudn, T. A and El Ohaleb, A F. (1999): An autbreake of cutneIfsterla] menlngo-encephallts in Dakahlia province. Zagazig Veternary Journal. 27(5), 122-134.

Evane, M. G. and Wateon, G. L. (1987) : Septicemic listeriosis in a reindeer call. Journal of Wildlife Diseases, 23(2). 314-317.

Fr. J. M.; Smith. G. M.; McOrath, M. C.: Speljers, E. J. and Allon. J. G. (1993) : Plasma and tissuc concentrations of a- tocopherol during vitamin E depletion In sheep. Brtish J Nutr, 69. 225-232.

Gray, M. L. and Kullinger, A. H. (1860): Ldsterta monocylogenes and Listerla infcetuons. Bacterlol. Rev. 30, 309-382.

Grzyb, K. and Gkorkowsk, E. F. (2008) : 
Creatlne kdnase isoenzymes characterization and functions in cell. Pogtepy Blochem. 54(3), 274-83.

Fitroshl Sabhinam, Knzuwort Kageyama, Toshiklro Guda and Atdo Ratcane (200B) ; Urocortin 2 Suppresses Host Restslance to Llsterla monocytogenealnfection va UpRegulation of Interleukn-10. Endocrnology. [46(1) 1), 5003-50 l I.

Joze, B.; Franc, K. and Tomaz, $z$. (2008) : Llsterla monocytogenes keratoconjunctfvits and uvelts in dairy cattle. Bull vet Inst Pulawy. 52, 351-355.

Kuida, K. J. A.; Lppke, G.; Ku, M. W.; Harding. D. J.; Livingaton, M. S. and Plavell, R. A. (1996) ; Altercd cytoklne export and apoptosis in mice defletent in interleukin1 beta converting enzyme. Sclence. 267 (5206), 2000-3.

Knmax, H.; Blngh, B. B.; Bal, M. B., Kmur, K.; Singh, R.; Bldhu, P. K. and Sandhu, K. S. (2007) : Patholog/cal and epldemlological investugations Into listerial encephalitls in sheep. Small Ruminant Research. 71, 293297.

Letb. B. and Tauber, M. (1989): Pathogenesis of bacterfal meningltis: Infectlous Disease Clinlcs of North America. 13(3), 527-548.

Low, J. C. and Renton, C. P. (1988) : Septicaemia, encephallus and abortlons in a housed flock of shcep caused by Listenta monocytogentes type 1/2. Vet Ree. $116(6), 147-50$.

Low, J. C. and Donachle, W. (1991) : Clinucal and scrum ankibody responses to lambs to infection by Ldsterla monocyrogenes. Res Vet Sel. 51 (2), 185-92.

Low. J. C. and Donachle. W. (1997) : A revlew of Listerla monocytogenes and Ilsteriosis. Veterinary Joumal 153. 9-29.

Oevormana, An: Botteron, C.; Qeuberllch.
T.; Nicoller, A.; Friee, M.; Dohert, M. G.; Helm, D.; Hitbe, M.; Zlmmer, $K_{\text {.; }}$ Zurbrygen, A and Vanderoldo, M. (2008) : Neuropathological survey of fallen stock: actlve su^ ${ }^{\wedge}$ vellance reveals high prevalence of encephaIItic listerosis in small ruminants, Vet Microbiol. 130(3-4),320-9.

Pau, E.; Orndorfin, Tern, 8.; Hamulckb, Idn; Wakhington Emoake and Edward $A$. Havella (2000) : Host and bacterlal factors in Usterlosis pathogenesis Veterinary MicrobloloDy. 114(1-2), 1-15.

Seellger, H. P. R. and Jones, D. (1980) : Genus Lusterla. In Lergey's manual of systematic bacterlology. Vol. 2 (P.H.A. Sneath \& J.G. Holt, eds). Wiltams Wilkans, Balumare. 1235-1245.

Selmlya, Y.; Ohmimin, $\mathbf{K}_{\text {; }}$ Itoh $\mathbf{H}$. and Murakami, R. (1902) : Lustertc septicemia whth mendngtis in a neonatal calf. $J$ Vet Med Scl. 54(6), 1205-7.

Semarad. 8. D. (1994) : Sepucenic llsterosIs, thrombocytopenta. blood parasitusm, and hepatopathy in a llama. J Am Vet Med Assoc. 204(2), 213-5.

Bhaw, F, D. (2008) : Sorbttol dehydrogenase in the dlagnosts of llver disease of rumlnants. Australtan Vetertnary Joumal. 50(6), $277-278$.

Shunyl gln, Jianzhong Gao and Kehe Huang (2007) : Effects of Different Selenum Sourees on Thusue Selentum Concentratuons, Blood GSH-Px Actrutues and Plasma Interieukin Levels In Fintshing Lambs. Bloloflcal Trace Element Research. 116,91-103.

Thompaon, B. T. (2008) : Glucose control In gepsls. Clln Chest Med, 29(4), 713-20.

Vaxques-Boland, J. A. Kuhn. M.: Berche, P.; Chalkaborty, T.; DominguezHernal, G.; Goebel, W.; Ganzalez-Zorn, B.; 
EI Boshy, M. E. and Gadalla, II. A.

Wehland, J. and Kreft, J. (2001) : Liste ria pathogenesls and moleeular wrulence determinanis. Clin. Miciobiol. Rev.14,584640.

Wood, J. B. (1972) : Enccphalitic Itsterogis In a hared of goats. Cand. Vet. Jour. 13(2), 80-82.
Yun-Zwong, F.: Bheng. $Y$, and Guoyao, w. U. (2002) ; Free radieals. antioxldants. and nutrition. Nutrtuon 18: 872-879

Zundel, E. and Bermard, 9. (2006) : Listeta manocytogenes transloeates throughout the digestive traet in asyniptomatc sheep. $J$ Med Microbtol, 55(12), 1717-23. 
Bt-Boshy. M. E. and Gadalla, H. A.

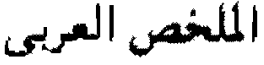

دراسات باثولوجيا إكلينيكية على تشخيص مرض الليستريا في الأغنام الأوسيمى

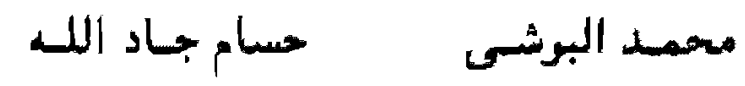

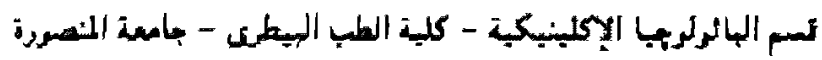

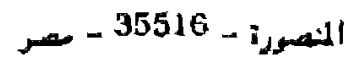

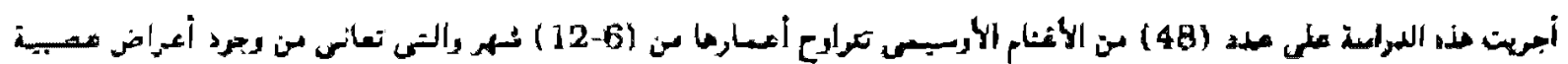

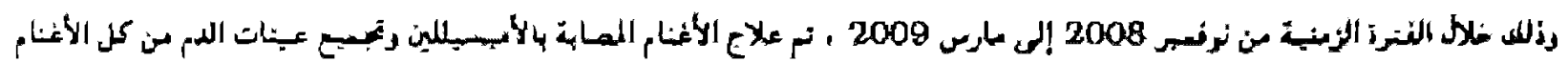

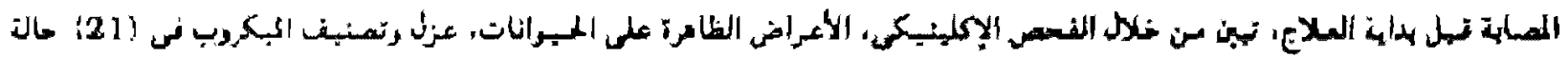

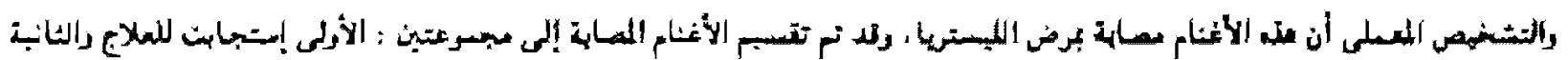

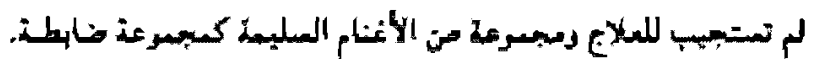

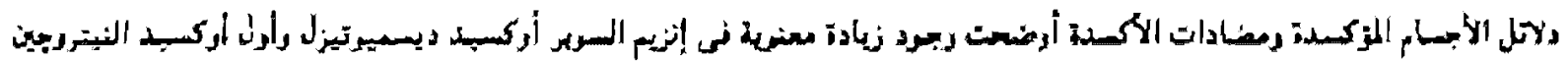

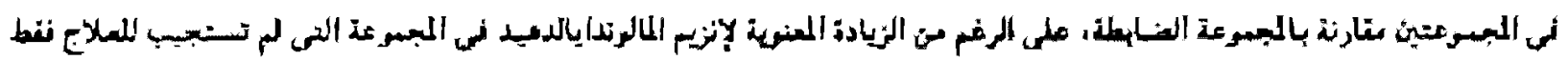

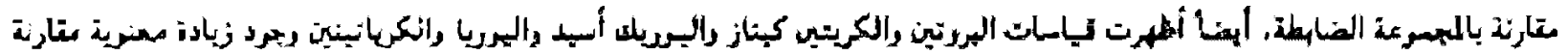

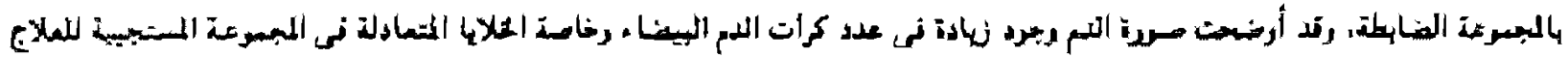

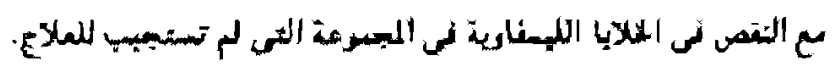

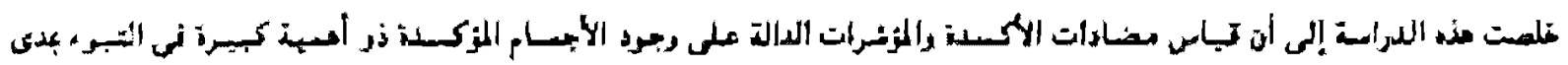

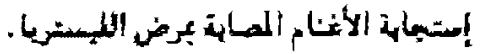

